\title{
IMAGINARIOS DE LA NACIÓN Y LA CIUDADANÍA EN CENTROAMÉRICA. ETHEL GARCÍA BUCHARD. (COORD.). SAN JOSÉ: EUCR, 2017
}

Adam Álvarez-Calderón

Recibido: 02/11/2018 - Aceptado: 05/11/2018

Este libro reúne trabajos de investigadoras e investigadores de Centroamérica adscritos al programa "Culturas políticas e identidades: Espacios públicos, poderes e imaginarios" del Centro de Investigación en Identidad y Cultura Latinoamericana (CIICLA), de la Universidad de Costa Rica. En la línea del objetivo central del programa, el libro, como conjunto, ofrece evidencias, análisis y reflexiones -en buena parte, en perspectiva histórica- sobre los procesos de construcción de imaginarios nacionales en Centroamérica. Esto lo hace a partir de indagaciones que dan cuenta de las representaciones, formas de legitimación y redes de poder; además de las esferas, prácticas y discursos sociales vinculados -política, arte, institucionalidad, entre otros-.

El estudio de la dimensión política de la cultura constituye un acceso prolífico para comprender los procesos de invención e imaginación nacionales y regionales. La apuesta por estudiar las interrelaciones entre lo político y lo cultural en sus interrelaciones es una de las virtudes del libro en tanto unidad de temáticas e interrogantes colectivas.

La primera parte, “Construyendo un nuevo orden: Prácticas, imaginarios y cultura política", cuenta con dos capítulos que analizan, principalmente, la importancia de las Cortes de Cádiz y la posterior Constitución emitida en 1812 como proceso histórico dinámico al cual hay que prestar atención para entender, en un contexto más amplio, la independencia centroamericana.

Así, Eduardo Madrigal, en “Cultura política, espacios públicos, poderes e imaginarios" -indagación historiográfica basada en la prosopografía y las redes de sociabilidad-, se pregunta por los actores políticos y las dinámicas sociales y de poder en este "período de transición" de ordenamientos sociopolíticos -sistema monárquico y sus especificidades en América a ordenamiento constitucional-, en el cual se evidencian continuidades en el dominio y ejercicio de poder de élites, los cuales conviven con ciertos indicios de cambio modernizante. 
En tanto, la editora del libro, Ethel García, en "Juramentación constitucional y ritualización del poder en la sociedad hondureña. Primeras décadas del siglo XIX", destaca la importancia del período anterior a la independencia, a propósito de los cambios -con sus continuidades y rupturas en cuanto al ejercicio de poder y discursividad modernizante- que se originan con el proceso de Cádiz. A partir del estudio de los rituales y ceremonias constitucionales -muchas caracterizadas por su majestuosidad, fastuosidad y teatralidad- busca dilucidar algunas de las formas de representación, consumo, legitimación del nuevo poder constitucional y su institucionalidad; también sus implicaciones sociales simbólicas, políticas y de poder. Ambos aportes contribuyen a pensar Cádiz como un proceso social más complejo, en ningún caso reducible a lo propiamente normativo.

En "La teatralidad del poder y la legitimación por los nuevos sujetos políticos", segunda parte del libro, se continúa profundizando en la ritualización del poder como parte de los mecanismos de legitimación social y construcción de imaginarios sociales y políticos. Por una parte, "La diosa Minerva como testigo de la Guatemala ideal en el imaginario de los liberales (1898-1920)” es el capítulo de Mynor Carrera en el cual interpreta Las Minervalias -fiestas cívicas celebradas en Guatemala durante la administración de Manuel Estrada Cabrera- como creación y legitimación de una idea de Estado-nación centrada en posicionar, por parte de la élite liberal, la modernidad, progreso, obediencia y respeto al Estado -en buena medida personificado en la figura autoritaria de Estrada Cabrera-. La relevancia social que estas fiestas adquieren se evidencia, entre otros aspectos, en el mantenimiento de prácticas o rituales religiosos con fines cívicos -Minerva como supuesta deidad "laica"-, procesos de racialización y jerarquización social persistentes.

A su vez, Patricia Fumero, en "Aproximaciones a la cultura política: Centroamérica y la conmemoración del centenario (septiembre, 1921)", dirige su atención a las celebraciones llevadas a cabo al cumplirse los cien años de independencia. Según el análisis de actividades realizadas en el marco del centenario, esta celebración permitió la participación de diversos sectores de los países centroamericanos, lo cual, de acuerdo con la interpretación de Fumero, da cuenta del sentimiento de unionismo predominante en dicho contexto. Cabe mencionar que, de cara al bicentenario de independencia, en el entorno relacional actual de las sociedades centroamericanas, resulta provocador repensar esta conclusión de la autora sobre el “sentimiento unionista" predominante en 1921: "identificarse como centroamericano primero y luego como nacional".

La última parte del libro, denominada "La apertura de espacios públicos y nuevos discursos e imágenes de la nación”, cuenta con tres capítulos que prestan atención a expresiones artísticas, políticas, instituciones y acciones vinculadas con la dimensión artística de la cultura. 
Laura Raabe analiza en "Una academia de bellas artes en Costa Rica: modernidad, nación y género (1897-1914)” la construcción de infraestructura, en específico, una academia de bellas artes de corte neoclásico -actividad constante desde la independencia en naciones de Latinoamérica-. La iniciativa fue parte del proceso de construcción de una idea de nación y proyecto político de élites liberales en el poder a finales del siglo XIX, con las repercusiones que esto tendría, por ejemplo, en el desarrollo paulatino de un "arte nacional" y en la educación de mujeres de la burguesía vallecentralista costarricense; aun cuando los roles de género que sustentaban el proyecto político y nacional de las élites liberales costarricenses se caracterizó por reproducir prácticas tradicionalistas, a pesar del discurso "modernizante" que difundían.

En “Impulso estatal al quehacer artístico de Costa Rica (1950-1980)”, Eugenia Zavaleta destaca algunos de los anclajes institucionales -leyes, creación de premios nacionales, infraestructura para actividades artísticas, certámenes, exposiciones, apoyo a artistas, compra de arte y otras prácticas- del modelo de Estado que se desarrollaba. La autora también destaca el efecto de estas acciones en el incremento de artistas en el país y la funcionalidad del marco político-jurídico-cultural del Estado en la construcción de los imaginarios nacionales deseados por el proyecto político en el poder.

Finalmente, "En busca de los invisibles hilos del discurso. Narrativas de intelectuales centroamericanos: Carlos Monge Alfaro, Pablo Antonio Cuadra y Roque Dalton" es el capítulo en que Patricia Alvarenga realiza una aproximación a las ideas sobre las identidades nacionales -sujeto histórico, representación y resignificación de imaginarios, jerarquías sociales, entre otros- en la obra producida entre 1940 y 1970 de estos tres intelectuales y escritores centroamericanos. Si bien Monge, Cuadra y Dalton asumieron posicionamientos políticos e ideológicos que promovían ideas de cambio y transformación social distintas, de acuerdo con lo que indica la autora, pueden encontrarse semejanzas en su discursividad en lo relativo a ciertas miradas totalizantes, esencialistas, deterministas sobre los procesos sociales.

En suma, las tres partes que componen el libro, desde distintas posibilidades de comprensión, contribuyen, según sus posibilidades, a los aportes promovidos desde hace algunas décadas por varios campos de estudio -historiografía, antropología, estudios culturales, entre otros- para profundizar y afinar los análisis e interpretaciones sobre el complejo proceso de construcción de los imaginarios e identidades nacionales

Este tipo de esfuerzos deberían ser también una invitación más a seguir comprendiendo la cultura y sus entornos relacionales como lugares desde los cuales acceder y pensar lo político. Lo anterior es importante, además, porque pensar las continuidades y resignificaciones de los imaginarios e identidades nacionales es tarea necesaria en un contexto -la Centroamérica actual- de desigualdad y violencia profunda.

Es también deseable que, desde la academia y otros espacios de investigación, discusión y reflexión amplia y diversa, se pueda buscar comprender el auge de proyectos políticos autoritarios, conservadores y fundamentalistas en varias partes del 
mundo -en cuenta Centroamérica-, su instrumentalización y resignificación de imaginarios nacionales anclados en construcciones históricas de un pasado idealizado que se pretende "rescatar" o "restaurar".

Adam Álvarez-Calderón. Costarricense. Antropólogo por la Universidad de Costa Rica. Coordina proyectos en el Servicio Jesuita para Migrantes Costa Rica -organización de la Red Jesuita con Migrantes Centroamérica y Norteamérica-. Ha participado en investigaciones del Observatorio Político Electoral Juvenil del Programa Agenda Joven de la Universidad Estatal a Distancia.

Contacto: adam.alvz@gmail.com

ORCID: 0000-0003-2375-2902 